\title{
RING Finger Protein 11
}

National Cancer Institute

\section{Source}

National Cancer Institute. RING Finger Protein 11. NCI Thesaurus. Code C29874.

RING finger protein 11 (154 aa, $17 \mathrm{kDa}$ ) is encoded by the human RNF11 gene. This protein plays a role in protein ubiquitination and degradation. 